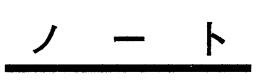

\title{
最近の業務用ファットスプレッドの品質特性について
}

\author{
小日山正剛・丸山 武紀・兼松＼cjkstart弘・新谷＼cjkstart勛 \\ 財団法人日本食品油脂検查協会 \\ ( 干103 東京都中央区日本橋浜町 3-27-8)
}

\section{Qualitative Characteristics of Recent Bakery Fat Spread}

\author{
Masatake KoHiy ama, Takenori MAruyama, Hiromu Kanematsu, and Isao NiIy A \\ Japan Institute of Oils \& Fats, Other Foods Inspection, Foundation \\ (3-27-8, Nihonbashi-Hamacho, Chuo-ku, Tokyo, ₹103)
}

Qualitative characteristics of recent products for bakery fat spreads were studied by measuring various chemical and physical parameters of 16 brands (multipurpose type 3 ; spice containing type 1 ; sweetened type 7 ; sweetened milkfat blend type 5).

1) The bakery fat spread contained lipid of $48.1 \sim 74.8 \%$ and protein of $0.27 \%$ or less, but salt was only slightly present or absent from all brands except one. Sugars including sucrose, glucose, fructose and others were present at about $20 \%$ in the sweetened products, which constitute majority of bakery fat spreads in Japan.

2) Analytical results on fatty acid composition indicated the fats to contain hardened fish oil in all brands except two, hardened rapeseed oil with laurin oil in No. 5 and hardened vegetable oil in No. 4. The characteristics of Cruciferae seed oil, probably mustard origin, were found in No. 4 , the spice containing type, while that of mikfat was confirmed in all brands of the sweetened milkfat blend type.

Nickel was detected at only 0.06 ppm or less in all fat spreads and was somewhat more in brands containing natural materials, such as milk products and mustard.

3) In bakery fat spreads, hardness increased in the order of the spice containing type $<$ multipurpose type $\leqq$ sweetened type<sweetened milkfat blend type, and depended essentially on the solid fat content of the separated oil, as has also been noted in bakery margarines previously reported. But, hardness appeared to also be influenced by other materials, such as sugars, stabilizers of emulsion and thickeners, Softer fat spreads shed their oil more easily, within the hardness index at about 120 or less. However, beyond this value, this feature was not apparent. Oil was shed with difficulty even at a hardness index exceeding 350 .

The creaming of sweetened fat spreads varied considerably and was closely correlated to the water-sorption index.

\section{1 緒 言}

さきに報告した業務用マーガリン類の品質調査 ${ }^{1)}$ に使 用した試料は，そのほとんどが日本農林規格 $(\mathrm{JAS})^{2)}$ では国際規格 ${ }^{3)}$ 亡同じ脂肪分 $80 \%$ 以上のマーガリンの うち「標準」に該当するものであり，一部に脂肪分 75 80\%の調製マーガリンも含まれていた。これに対し，摂 取カロリー低減化を目的としたファットスプレッドは脂 肪分 35〜 75\% と規定され，これが予想以上の速さで増
えており, 前報 ${ }^{4)}$ ではそのうち家庭用のものについて報 告した。

業務用のマーガリンとファットスプレッドの生産量を みると, 次表に示すようにマーガリンの横ばいに対して ファットスプレッドの増加傾向がみられる。業務用 ファットスプレッドの大部分は加糖製品であり, その一 部はさらに果実加工品, コーヒ一等を加えた風味ファッ トスプレッドもある。これらの加糖製品は主にベーカ リー製品のフィリング，トッピング，コーティング用之 


\begin{tabular}{c|c|c|c|c|c}
\hline & 1986 & 1987 & 1988 & 1989 & $1990^{*}$ \\
\hline 業 務用マーガリン** & $148,918 \mathrm{t}$ & $149,701 \mathrm{t}$ & $152,862 \mathrm{t}$ & $151,461 \mathrm{t}$ & $150,500 \mathrm{t}$ \\
業務用ファットスプレッド & 16,536 & 17,972 & 18,846 & 19,884 & 21,000 \\
\hline 合 & 165,454 & 167,743 & 171,708 & 171,345 & 171,500 \\
\hline
\end{tabular}

*: 生産計画

**：調製マーガリンを含む。

して消費され，ビスケット等のサンドクリーム用に使用 されるものもある5)。また，無糖製品は主にパン等への 礼り込み用であり, 香辛料, 特にからしを加えた風味 ファットスプレッドはレストランや給食会社でサンド ウィッチ用に使用されている。従って, その使用目的は 業務用マーガリンとはかなり異なり, またその性状は家 庭用のものとは異なると考えられる。

そこで, 前報 ${ }^{4}$ の家庭用に引き続いて業務用ファット スプレッドの品質特性について調査したので報告する。

\section{2 実験}

\section{$2 \cdot 1$ 試 料}

業務用ファットスプレッドは, 10 製造工場から入手 した 16 銘柄 (万能型 $3:$ スプレッド用の香辛料含有型 1 ; 加糖型 7 ; 乳脂混合加糖型 5) を試料とした。これら はいずれも平成元年 9,10 月製造のもので, 香辛料含有 型のみ風味ファットスプレッドである。

\section{$2 \cdot 2$ 方 法}

$2 \cdot 2 \cdot 1$ 化学的性状

水分, 脂質, タンパク質, 塩分, 鉄, 銅, 鉛, 七素, ニッケル, 分離油脂のけん化価 (SV), ヨウ素価 (IV), 酪酸価, エレックス装置による上昇融点 (EMP) 及び軟 化点 (ESP) 並びに脂肪酸組成は, 前報の家庭用 ${ }^{6)}$ 及び 業務用マーガリン類 ${ }^{1}$ 並びに家庭用のファットスプレッ ド4) 及び調理用マーガリンク)の場合と同じ方法で測定し た。乳化剤についても基本的に同様の方法で分析した が，モノグリセリド及びショ糖脂肪酸エステルの定量は 次のように行った。試料からのテトラヒドロフラン抽出 物をシリカゲルカラムクロマトグラフィーにより, まず $10 \%$ エーテル・ベンゼン混合溶媒で洗浄後, エーテル でモノグリセリド，ついでメタノールでショ糖脂肪酸エ ステルを分別溶出し, 以後それぞ梅近報告した操作手 順の高速液体クロマトグラフィーでモノグリセリド8) 及 びショ糖脂肪酸エステル ${ }^{9)}$ を定量した。

糖類は, 水で抽出後, すでに報告したガスクロマトグ ラフィー ${ }^{10)}$ で分別定量した。

\section{$2 \cdot 2 \cdot 2$ 物理的性状}

円すい針入度に上る硬度指数, 遊離液体油量 (oil-off 值), クリーミング価及び分離油脂の個体脂含量 (SFC) (前報の家庭用 ${ }^{6)}$ 及び業務用マーガリン類 ${ }^{1)}$ の場合之同
方法で測定した。

吸水性についてはすでに報告 ${ }^{10}$ したように, クリー ミング価の測定操作に従って $40 \mathrm{~min}$ 試料をクリーミン グさせたのち， $20 \mathrm{~mL} / \mathrm{min}$ の割合で水を加えながら Kenwood ミキサーでかくはんし, 水之試料が混和しな くなる状態を終点とし, 得られた吸水量 $(\mathrm{mL})$ を試料 重量 $(\mathrm{g})$ で除して吸水量指数を求めた。

\section{3 結果及び考察}

\section{1 化学的性状}

$3 \cdot 1 \cdot 1$ 一般性状及び食品添加物

業務用ファットスプレッドの一般性状について Table -1 に示す。なお, 国際規格之の関連で鉄, 銅等の金属 類も付記した。マーガリンに比べ, ファットスプレッド は脂肪分が少ないため相対的に水分が多くなり, 糖無添 加の万能型及びスプレッド用の香辛料含有型でも（水分 21.4 31.8\%, 脂質 63.5 74.8\%) 同様であった。しか (家庭用 ${ }^{6)}$ の場合, タンパク質等油脂及び水分以外の成 分も多くなり, しかも油脂含有率の幅も広いことから油 脂含有率と水分の合計值 ${ }^{2}$ を $85 \%$ 以上之規定されてい る。これに対し，業務用に多い加糖や風味原料添加のも のにはその合計値は $65 \%$ 以上之規定され, 両加糖型の 結果も無糖タイプより少なかった。タンパク質では, 最 高のNo. 1 でも $2.7 \%$ 上家庭用 ${ }^{4)}$ のように高いものは見 当たらないが, 全平均值は $0.93 \%$ とほとんど差がな く，また植物性タンパク使用のNo. 1 を除いていずれ も脱脂乳由来のものであった。食塩は $2.3 \%$ の N . 1 を除いて微量もしくは無添加であった。

分離油脂の EMP 及び ESP は, それぞれ 27.3 35.7 ${ }^{\circ} \mathrm{C}$ 及び 25.4 33.2 $2^{\circ} \mathrm{C}$ で, 銘柄により多少差はあるが, 2 方法による融点には夕イプによる差はほとんどみられな かった。SV及びIVも，それぞれ 184.7〜202.6 及び 57.6 92.2で, 同様にタイプによる特徵はみられなかっ た。また, 乳脂混合加糖型の酪酸価は $1.0 \sim 4.8$ で, こ れから推測される乳脂含有率は JAS ${ }^{21}$ の基準に適合し た。なお, 鉛及びヒ素は全試料から検出されず, 鉄及び 銅は最高でもそれぞれ 1.26 (No. 3) 及び $0.06 \mathrm{ppm}$ (No. 1, 4) で, これらは前報の家庭用調理用マーガリ ンの場合 ${ }^{7)}$ よわずかに高いもののいずれも食用油脂製 品の 1 例であるマーガリンの国際規格 ${ }^{3)}$ の基準に合致し 
Table-1 General properties of bakery fat spread.

\begin{tabular}{|c|c|c|c|c|c|c|c|c|c|c|c|c|c|c|c|}
\hline \multirow{2}{*}{ Type } & \multirow{2}{*}{ No. } & \multirow{2}{*}{$\begin{array}{c}\text { Water } \\
(\%)\end{array}$} & \multirow{2}{*}{$\begin{array}{c}\text { Lipid } \\
(\%)\end{array}$} & \multirow{2}{*}{$\begin{array}{c}\text { Protein } \\
(\%)\end{array}$} & \multirow{2}{*}{$\begin{array}{l}\text { Salt } \\
(\%)\end{array}$} & \multirow{2}{*}{$\begin{array}{c}\mathrm{Fe} \\
(\mathrm{ppm})\end{array}$} & \multirow{2}{*}{$\begin{array}{c}\mathrm{Cu} \\
(\mathrm{ppm})\end{array}$} & \multirow{2}{*}{$\begin{array}{c}\mathrm{Pb} \\
(\mathrm{ppm})\end{array}$} & \multirow{2}{*}{$\begin{array}{c}\text { As } \\
(p p m)\end{array}$} & \multirow{2}{*}{$\begin{array}{c}\mathrm{Ni} \\
(\mathrm{ppm})\end{array}$} & \multicolumn{5}{|c|}{ Separated oil } \\
\hline & & & & & & & & & & & $\begin{array}{l}\text { EMP } \\
\left({ }^{\circ} \mathrm{C}\right)\end{array}$ & $\begin{array}{l}\text { ESP } \\
\left({ }^{\circ} \mathrm{C}\right)\end{array}$ & SV & IV & $\begin{array}{l}\text { Butyric } \\
\text { acid number }\end{array}$ \\
\hline \multirow[t]{4}{*}{ Multipurpose type } & 1 & 21.3 & 71.3 & 2.7 & 2.3 & 1.22 & 0.06 & nd & nd & 0.01 & 31.9 & 26.9 & 72.8 & 190.3 & \\
\hline & 2 & 24.7 & 74.8 & $<0.1$ & 0.2 & 0.26 & nd & nd & nd & nd & 34.5 & 30.5 & 83.0 & 189.7 & \\
\hline & 3 & 31.8 & 63.5 & 2.2 & 0.2 & 1.26 & 0.05 & nd & nd & 0.01 & 30.5 & 27.8 & 92.2 & 190.9 & \\
\hline & $\bar{x}$ & 25.9 & 69.9 & 1.7 & 0.9 & 0.91 & 0.04 & & & 0.01 & 32.3 & 28.4 & 82.7 & 190.3 & \\
\hline Spice containing type & 4 & 21.4 & 73.9 & 0.5 & 1.8 & 0.94 & 0.06 & nd & nd & 0.06 & 31.7 & 25.4 & 90.9 & 184.7 & \\
\hline \multirow[t]{8}{*}{ Sweetened type } & 5 & 28.9 & 48.1 & 1.0 & $<0.1$ & 0.26 & 0.03 & nd & nd & 0.01 & 35.2 & 30.7 & 57.6 & 202.6 & \\
\hline & 6 & 19.8 & 62.2 & 0.3 & $<0.1$ & 0.34 & 0.02 & nd & nd & 0.01 & 33.8 & 31.0 & 59.3 & 195.4 & \\
\hline & 7 & 15.9 & 63.8 & 0.8 & 0.1 & 0.56 & 0.01 & nd & nd & nd & 35.7 & 33.2 & 68.9 & 193.4 & \\
\hline & 8 & 15.5 & 57.6 & 0.6 & 0.1 & 0.17 & 0.02 & nd & nd & 0.01 & 34.7 & 31.3 & 81.8 & 189.0 & \\
\hline & 9 & 27.4 & 51.7 & 2.3 & 0.2 & 1.13 & 0.04 & nd & nd & 0.01 & 32.5 & 30.7 & 89.8 & 189.0 & \\
\hline & 10 & 22.2 & 56.7 & 1.4 & $<0.1$ & 0.63 & 0.02 & nd & nd & 0.05 & 34.5 & 32.3 & 75.5 & 190.3 & \\
\hline & 11 & 18.2 & 61.4 & 1.5 & 0.1 & 0.49 & 0.03 & nd & nd & nd & 32.4 & 28.0 & 90.0 & 189.0 & \\
\hline & $\bar{x}$ & 21.1 & 57.4 & 1.1 & 0.1 & 0.51 & 0.02 & & & 0.01 & 34.1 & 31.0 & 74.7 & 192.7 & \\
\hline \multirow{6}{*}{$\begin{array}{l}\text { Sweetened milkfat } \\
\text { blend type }\end{array}$} & 12 & 13.1 & 68.5 & 0.2 & $<0.1$ & 0.16 & 0.01 & nd & nd & 0.05 & 27.3 & 29.0 & 61.4 & 200.8 & 4.8 \\
\hline & 13 & 16.1 & 60.3 & 0.3 & $<0.1$ & 0.27 & nd & nd & nd & nd & 33.4 & 29.1 & 69.7 & 196.3 & 1.2 \\
\hline & 14 & 16.9 & 62.5 & 0.6 & $<0.1$ & 0.24 & 0.01 & nd & nd & 0.02 & 35.3 & 30.8 & 68.8 & 193.4 & 2.0 \\
\hline & 15 & 12.7 & 65.1 & $<0.1$ & 0.0 & 0.22 & 0.01 & nd & nd & 0.02 & 33.8 & 29.7 & 68.7 & 193.4 & 1.0 \\
\hline & 16 & 16.1 & 62.2 & 0.5 & 0.1 & 0.24 & 0.01 & nd & nd & 0.05 & 33.9 & 29.6 & 68.9 & 195.8 & 1.9 \\
\hline & $\bar{x}$ & 15.0 & 63.7 & 0.3 & $<0.1$ & 0.23 & 0.01 & & & 0.03 & 32.7 & 29.6 & 67.5 & 195.9 & 2.2 \\
\hline
\end{tabular}

EMP : Open tubed melting point by Elex apparatus, ESP : Softing point by Elex apparatus,

SV : Saponification value, IV : Iodine value, nd : not detected

Table-2 Sugars and food additives in bakery fat spread.

\begin{tabular}{|c|c|c|c|c|c|c|c|c|c|c|c|c|}
\hline \multirow{2}{*}{ No. } & \multicolumn{6}{|c|}{ Sugar (\%) } & \multirow{2}{*}{$\begin{array}{c}\text { Sorbitol } \\
(\%)\end{array}$} & \multicolumn{3}{|c|}{ Emulsifier (\%) } & \multirow{2}{*}{$\begin{array}{l}\text { Stabilizer } \\
\text { of emul- } \\
\text { sion }\end{array}$} & \multirow{2}{*}{ Thickener } \\
\hline & Fructose & Glucose & Sucrose & Lactose & Maltose & Total & & $\mathrm{MG}$ & Lecithin & $\mathrm{SE}$ & & \\
\hline $\begin{array}{l}1 \\
2 \\
3\end{array}$ & & & & & & & & $\begin{array}{c}0.94 \\
0.41 \\
\text { nd }\end{array}$ & $\begin{array}{c}\text { nd } \\
0.03 \\
0.02\end{array}$ & $\begin{array}{c}1.19 \\
\text { nd } \\
\text { nd }\end{array}$ & & \\
\hline 4 & & & & & & & & 0.35 & 0.02 & nd & & \\
\hline 5 & 0.0 & 12.0 & 6.7 & 3.4 & 0.0 & 22.1 & 0.0 & 0.19 & 0.02 & 0.42 & & \\
\hline 6 & 0.0 & 0.0 & 17.6 & 0.5 & 0.0 & 18.1 & 0.0 & 0.33 & nd & nd & & \\
\hline 7 & 0.0 & 0.0 & 18.2 & 1.2 & 0.0 & 19.4 & 0.0 & 0.44 & nd & nd & & \\
\hline 8 & 0.0 & 1.4 & 17.1 & 1.3 & 6.5 & 26.3 & 0.0 & nd & 0.02 & nd & & \\
\hline 9 & 4.0 & 5.2 & 5.0 & 2.5 & 1.8 & 18.5 & 0.0 & nd & 0.03 & 0.16 & & 0 \\
\hline 10 & 0.0 & 11.1 & 8.7 & 0.0 & 0.0 & 19.8 & 0.0 & nd & nd & 0.10 & 0 & \\
\hline 11 & 0.0 & 0.0 & 16.8 & 2.0 & 0.0 & 18.8 & 0.0 & 0.22 & 0.01 & nd & & \\
\hline 12 & 0.1 & 0.2 & 14.4 & 4.0 & 0.4 & 19.1 & 0.0 & 0.45 & nd & nd & & \\
\hline 13 & 0.0 & 0.0 & 21.8 & 0.8 & 0.0 & 22.6 & 0.0 & 0.11 & nd & nd & & \\
\hline 14 & 0.0 & 0.0 & 19.0 & 0.8 & 0.0 & 19.8 & 0.0 & 0.10 & nd & nd & & \\
\hline 15 & 1.8 & 2.0 & 12.3 & 0.0 & 4.9 & 21.0 & 0.0 & 0.11 & nd & nd & & \\
\hline 16 & 1.3 & 2.3 & 10.8 & 0.7 & 0.5 & 15.6 & 3.7 & 0.14 & nd & nd & & \\
\hline
\end{tabular}

$O$ : Labelled on the package, MG : Monoglycerides, SE : Sucrose esters of fatty acids 
た。硬化油製造の触媒でもあるニッケルについては，万 能型及び No. 10 以外の乳脂を含まぬ加糖型からは検出 しないか定量限界に近い $0.01 \mathrm{ppm}$ にすぎないが，香辛 料含有型 $(0.06 \mathrm{ppm})$, No. 13 以外の乳脂混合加糖型 (0.02 0.05 ppm) 及び後述のカゼインナトリウムのよ うな乳化安定剤添加の No. 10 (0.05 ppm) でやや多 かった。これは，業務用ファットスプレッドに含まれる ニッケルが硬化油を含む原料油脂よりも，むしろ約 0.1 $\mathrm{ppm}$ またはそれ以上を含むとの報告 ${ }^{11)}$ がある香辛料 （からし）や乳製品のような天然食品素材に由来するよ うであり，この点については今後検討する必要があろ う。

試料に含まれる糖類及び食品添加物を Teble-2 に示 す。糖については, 両加糖型に総量として 15.6 26.3\% $(\bar{x} 20.0 \%)$ 含まれ，そのうち 9 銘柄はショ糖, 2 銘柄 はぶじう糖が主成分であり，残る 1 銘柄は果糖及びぶよ゙ う糖がそれぞれ 4.0 及び $5.2 \%$ 含まれることから異性化 糖主体と思われる。なお，No. 16 には $3.7 \%$ のソルビ トールが含まれていた。乳化剤では, 12 銘柄から0.10 0.94\%のモノグリセリド， 7 銘柄から $0.01 〜 0.03 \%$ の レシチン及び 4 銘柄から $0.10 \sim 1.19 \%$ のショ糖脂肪酸 エステルが検出された。その他No. 9 にはキサンタン ガム等ののり(糊)料, No. 10 にはカゼインナトリウム 等の乳化安定剂が使用されていた。乳化剂として主にモ ノグリセリド又はレシチンもしくはその両方が使用され ていたことは業務用マーガリン類 ${ }^{1)}$ の場合之同様であっ た。しかし業務用マーガリン類と異なり，ショ糖脂肪酸 エステルの使用例がやや多く, 特にNo.1のようにモ
ノグリセリドとともに約 $1 \%$ ずつと比較的多量に添加さ れたこと及びNo. 9 のように糊料と併用されたことは水 分が多いか又は糖を含むファットスプレッドの乳化とそ の安定性及び業務用としての加工特性の改善を考慮した もの之推察される。なお, No. 2 のソルビン酸カリウム 添加以外に合成の酸化防止剂及び保存料は使用されてい ない。

\section{$3 \cdot 1 \cdot 2$ 脂肪酸組成}

業務用ファットスプレッドから分離した脂肪分の脂肪 酸組成を Teble-3 に示す。万能型では，いずれも奇 数酸, $14: 1$ の検出及び比較的多い $16: 1$ という動物油 脂の特徵と之もに炭素数 20 以上の長鎖モノ不飽和酸,

特にそのトランス酸の検出から原料油脂への硬化魚油の 配合が推測され, この硬化魚油の特徵は両加糖型でも No. 5 以外で認められた。これに対しNo. 5 並びに香辛 料含有型の No. 4 では動物油脂の特徵がみられないが, 18：1 及び $18 ： 2$ のトランス酸が検出されたことから植 物硬化油の使用は明らかである。また, No. 5 では 58.1 $\%$ の総 $18: 1$ と微量の $22: 1$, 並びに $12.3 \%$ の $12: 0$ と 微量の $10: 0$ が検出されたことから低エルカ酸型の硬 化なたね油主体でラウリン系油脂配合が, そしてNo. 4 では 7.4\%の 20：1 とともに $22 ： 1$ が 15.3\% と特に 多い亡いう十字科植物の種子油の特徴がみられ, さらに いずれもシス型のみであったことから，これらの長鎖モ ノ不飽和酸は風味原料としてのからし（油を含む）由来 之推測された。なお乳脂混合加糖型では，炭素数 12 以 下の短鎖脂肪酸, 特に $4: 0,6: 0$ という乳脂の特徵が みられ, 前述の酪酸価とともに原料油脂表示が確認され

Table-3 Fatty acid composition of oil separated from bakery fat spread.

(\%)

\begin{tabular}{|c|c|c|c|c|c|c|c|c|c|c|c|c|c|c|c|c|c|c|c|c|c|c|c|c|c|c|}
\hline \multirow{2}{*}{ No. } & \multirow{2}{*}{$4: 0$} & \multirow{2}{*}{$6: 0$} & \multirow{2}{*}{$8: 0$} & \multirow{2}{*}{$10: 0$} & \multirow{2}{*}{$12: 0$} & \multirow{2}{*}{$14: 0$} & \multirow{2}{*}{$14: 1$} & \multirow{2}{*}{$15: 0$} & \multirow{2}{*}{$16: 0$} & \multirow{2}{*}{$16: 1$} & \multirow{2}{*}{$17: 0$} & \multirow{2}{*}{$17: 1$} & \multirow{2}{*}{$18: 0$} & \multicolumn{2}{|c|}{$18: 1$} & \multicolumn{3}{|c|}{$18: 2$} & \multirow{2}{*}{$18: 3$} & \multirow{2}{*}{$20: 0$} & \multicolumn{2}{|c|}{$20: 1$} & \multirow{2}{*}{ 22:0 } & \multicolumn{2}{|c|}{$22: 1$} & \multirow{2}{*}{ Others } \\
\hline & & & & & & & & & & & & & & $t$ & $c$ & $t t$ & $t c+c t$ & $c c$ & & & $t$ & $c$ & & $t$ & $c$ & \\
\hline 1 & & & & & 0.4 & 5.1 & 0.4 & 0.4 & 21.1 & 7.1 & 1.2 & 0.7 & 9.3 & 4.8 & 22.6 & & 0.5 & 3.0 & 0.5 & 0.6 & 2.8 & 6.2 & 0.2 & 2.3 & 4.1 & 6.7 \\
\hline 2 & & & & & & 6.0 & & 0.3 & 17.9 & 7.3 & 1.3 & 0.5 & 5.3 & 6.2 & 16.9 & 0.2 & 0.8 & 4.6 & 1.5 & 1.3 & 4.6 & 5.3 & 0.7 & 3.7 & 2.6 & 13.0 \\
\hline 3 & & & & & 0.1 & 4.5 & 0.2 & 0.3 & 15.1 & 6.0 & 0.9 & 0.4 & 4.1 & 5.0 & 26.8 & 0.1 & 0.5 & 8.9 & 3.6 & 0.9 & 4.5 & 4.4 & 0.4 & 3.8 & 2.6 & 6.9 \\
\hline 4 & & & & & & 0.4 & & & 10.0 & 0.5 & & & 5.8 & 11.0 & 27.1 & & 0.4 & 12.0 & 6.8 & 0.7 & & 7.4 & 0.3 & & 15.3 & 2.3 \\
\hline 5 & & & & 0.8 & 12.3 & 4.5 & & & 6.0 & 0.3 & & & 11.3 & 27.5 & 30.6 & 0.8 & 2.7 & 0.2 & 0.3 & 0.5 & & 1.1 & 0.3 & & 0.5 & 0.3 \\
\hline 6 & & & & & 0.5 & 4.9 & 0.4 & 0.4 & 20.8 & 4.5 & 0.8 & 0.4 & 6.3 & 8.9 & 25.7 & & 0.3 & 6.1 & 1.6 & 0.8 & 2.9 & 3.2 & 0.4 & 1.4 & 2.6 & 7.1 \\
\hline 7 & & & & & 0.7 & 5.8 & & 0.8 & 18.2 & 5.8 & 1.0 & 0.5 & 7.1 & 13.1 & 18.2 & & 0.7 & 3.3 & 0.6 & 1.4 & 4.6 & 4.8 & 1.8 & 1.7 & 4.9 & 5.0 \\
\hline 8 & & & & & 0.3 & 5.4 & & 0.5 & 17.1 & 6.4 & 1.1 & 0.5 & 5.4 & 9.1 & 20.6 & & 0.3 & 5.5 & 2.0 & 1.0 & 2.7 & 4.7 & 0.6 & 3.3 & 4.1 & 9.4 \\
\hline 9 & & & & & & 4.2 & & 0.2 & 14.8 & 4.9 & 0.6 & 0.2 & 4.8 & 5.6 & 28.6 & & 0.1 & 4.0 & 4.1 & 1.1 & 3.0 & 5.7 & 0.6 & 1.7 & 4.5 & 11.3 \\
\hline 10 & & & & & 0.1 & 2.7 & & 0.1 & 17.8 & 3.1 & 0.3 & 0.1 & 5.7 & 11.0 & 33.9 & & 0.6 & 8.3 & 3.0 & 0.7 & 2.9 & 3.0 & 0.3 & 1.6 & 2.5 & 2.3 \\
\hline 11 & & & & & 0.6 & 4.5 & & 0.2 & 14.3 & 5.3 & 0.6 & 0.2 & 4.3 & 5.2 & 28.1 & & 0.4 & 8.9 & 3.9 & 0.8 & 2.4 & 2.3 & 0.4 & 1.9 & 1.2 & 14.5 \\
\hline 12 & 1.0 & 0.9 & 1.1 & 1.6 & 1.5 & 5.7 & 0.5 & 0.5 & 20.6 & 4.5 & 0.5 & 0.2 & 6.1 & 13.7 & 24.1 & 0.1 & 1.5 & 3.0 & 0.5 & 0.6 & 2.7 & 2.8 & 0.3 & 1.8 & 2.1 & 2.1 \\
\hline 13 & 0.9 & 0.6 & 1.0 & 1.0 & 3.6 & 5.1 & 0.4 & 0.4 & 17.0 & 4.3 & 0.7 & 0.5 & 5.5 & 16.3 & 22.4 & & 0.9 & 3.5 & 1.4 & 0.6 & 2.4 & 3.8 & 0.4 & 1.9 & 2.1 & 3.3 \\
\hline 14 & 0.7 & 0.5 & 0.4 & 0.6 & 0.6 & 3.9 & 0.2 & 0.3 & 18.7 & 3.7 & 0.6 & 0.3 & 6.6 & 15.5 & 27.4 & & 1.2 & 3.2 & 1.2 & 1.0 & 3.1 & 3.4 & 0.3 & 1.9 & 2.5 & 2.2 \\
\hline 15 & 0.6 & 0.4 & 0.4 & 0.5 & 0.6 & 4.3 & 0.3 & 0.4 & 21.7 & 4.1 & 0.7 & 0.4 & 5.9 & 16.1 & 24.5 & & 1.1 & 3.7 & 0.1 & 0.8 & 2.9 & 3.0 & 0.2 & 2.2 & 2.1 & 3.0 \\
\hline 16 & 0.8 & 0.7 & 0.5 & 0.6 & 0.9 & 5.0 & 0.5 & 0.5 & 20.9 & 4.5 & 1.0 & 0.5 & 4.9 & 14.3 & 27.9 & & 0.9 & 3.5 & 0.9 & 0.5 & 1.7 & 3.0 & 0.3 & 1.5 & 1.9 & 2.3 \\
\hline
\end{tabular}


た。

一方, リノール酸 $(c, c-18: 2)$ は No. 4 以外のす べてで $10 \%$ 未満であり, 家庭用 ${ }^{4}$ の場合よりかなり低 かった。これは, 家庭用とは用途が異なり, 業務用では 栄養効果より物性, 加工特性を重視したためで, これ はマーガリンの場合 ${ }^{1)}$ と同様である。香辛料含有型の No. 4 で $12.0 \%$ とやや高かったのは, 業務用でもサンド ウィッチ用として家庭用同様のスプレッド目的の製品の ためであろう。

\section{$3 \cdot 2$ 物理的性状}

製品の硬度指数をそれぞれタイプ別平均值で Fig. - 1,

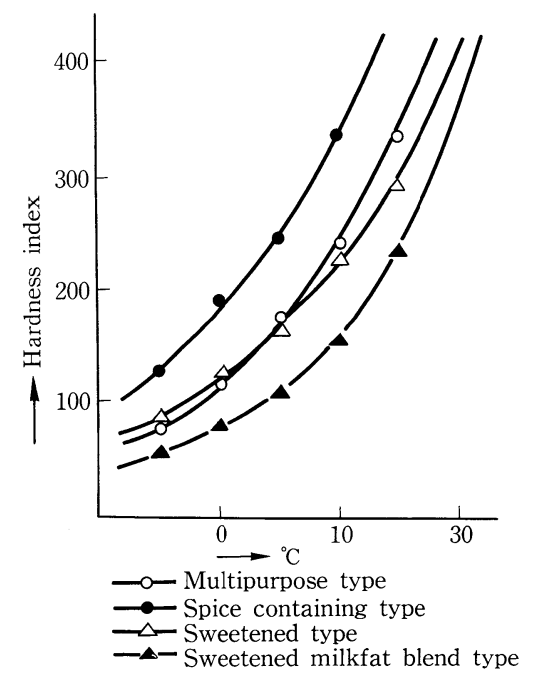

Fig.-1 Comparison of hardness index curves in different types of bakery fat spread.

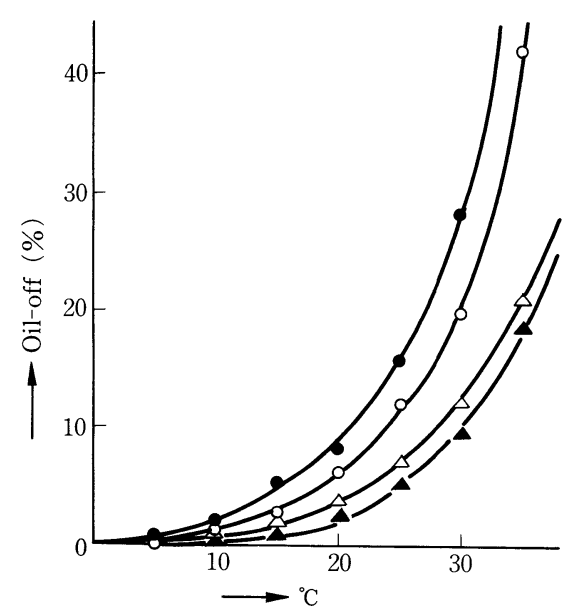

For marks, see Fig.- 1

Fig.-2 Comparison of oil-off curves in different types of bakery fat spread. oil一off 值の場合を Fig. -2 , そして分離油脂の SFC の 場合を Fig. -3 に図示する。硬度指数曲線では, 全温度 領域で業務用でも家庭用と同椂にスプレッドを目的とす る香辛料含有型 (No. 4) がもっとも軟らかく, ついで 万能型と加糖型間にはほとんど差がなく, 乳脂混合加糖 型がもっとも硬いことを示した。これに対し, oil-off 曲線では香辛料含有型がもっとも oil-off しやすく, 乳 脂混合加糖型がもっとも oil-off し難しいことを示し, また分離油脂の $\mathrm{SFC}$ 曲線では全温度領域で前者がもっ とも低く, 後者がもっとも高かった。従って, 製品の硬 さは原料油脂の SFCに依存し, 軟らかいものほよ゙ oiloff しやすいという家庭用マーガリンで得られた推論は 業務用ファットスプレッドでも基本的に同じように思わ 机る。しかし, 硬さには差がないにもかかわらず加糖型

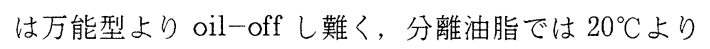
低温になるほじ高くなり, その oil-off 及び SFC 曲線

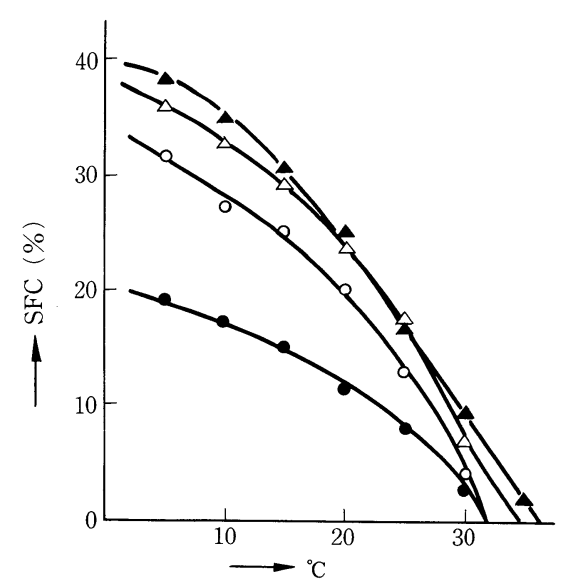

For marks, see Fig.- 1

Fig. -3 Comparison of SFC curves in different types of bakery fat spread.

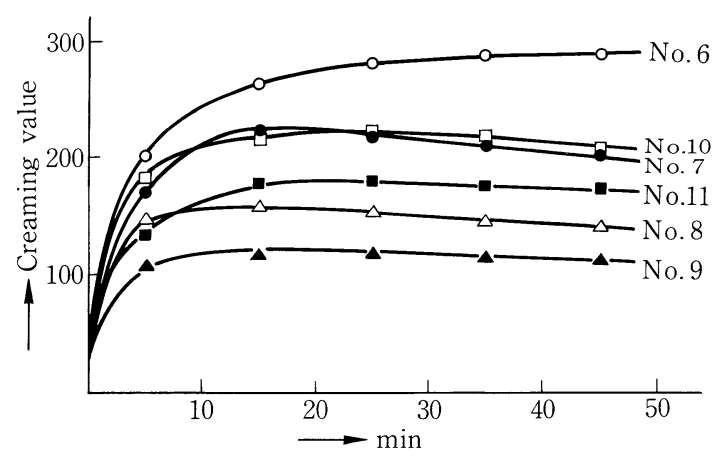

Fig. -4 Change in creaming values of bakery fat spreads in the sweetened type. 


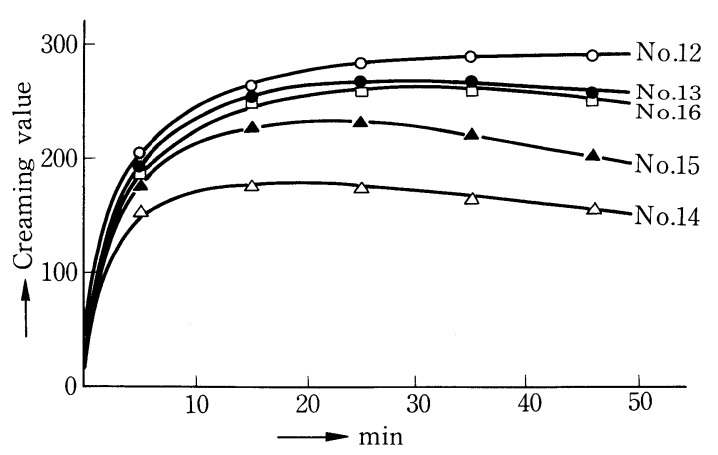

Fig. -5 Change in creaming values of bakery fat spreads in the sweetened milkfat blend type.

はむしろ乳脂混合加糖型に近かった。

加糖ファットスプレッドはホイップするだけ又はその ままでバ夕ークリームやビスケットのサンドクリーム として使用できる利点がある ${ }^{5)}$ 。そこで, 加糖型及び乳 脂混合加糖型のクリーミング性を調べた結果をそれぞれ Fig. -4 及び Fig. -5 に示す。なお, No. 5 は測定不能 であった。乳脂を含ま加糖型では No. 6, 乳脂混合加 糖型ではNo. 12 がもっとも優れたクリーミング性を示 したが, 両型とも銘柄間の差が大きいため夕イプによる 特徵はみられなかった。これは, 業務用マーガリン 異なり湘定不能の No. 5 が $\mathrm{O} / \mathrm{W}$ 型であるなど乳化状態 が銘柄間で相異がみられたことによるものであろう。

\section{$3 \cdot 3$ 物理的特数及び化学的組成亡の関連}

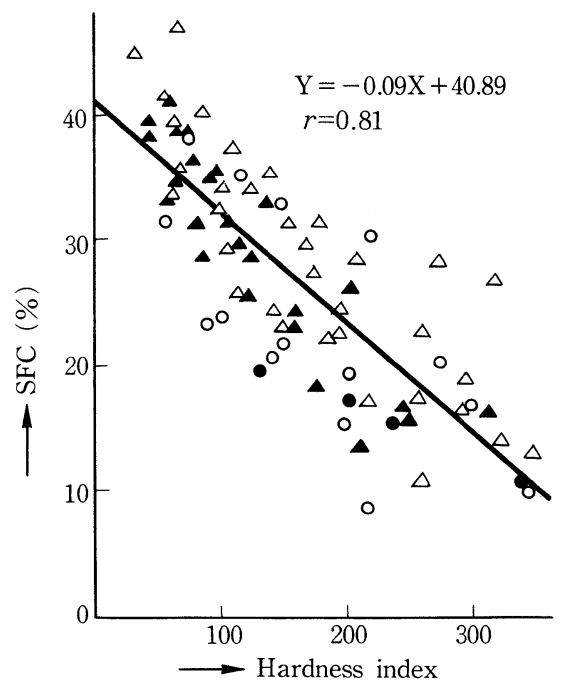

For marks, Fig.- 1

Fig. -6 Plot of SFC us hardness index for bakery fat spread.
前報の業務用マーガリン類 ${ }^{1)}$ 亡同様に業務用ファット スプレッドについても物理的特数及び脂肪酸組成との関 連性を調べた。硬度指数と分離油脂の SFC との関係は Fig. -6に示すようにやや高い負の相関がみられた $(r=$ $-0.81)$ が, 業務用マーガリン類の場合 $(-0.92)^{1)}$ に比 べ相関係数 (絶対值) が低く，回帰直線からのばらつき もやや大きかった。これは，業務用ファットスプレッド の硬さも基本的には原料油脂の SFC に依存するが，糖 類等の添加成分にも影響されることを示している。ま た，硬度指数と oil-off 值の関係も Fig. -7 に示すよう に業務用マーガリン類 ${ }^{1)}$ と同様に硬度指数約 120 以下で は軟らかいものほよ゙ oil-off しやすい傾向を示すもの の，それ以上では水分が多く，糖類等も含まれるためさ らにばらつきが大きくなり，相関が認められなかった。 しかし, 硬度指数 350 以上と軟らかすぎるため硬度測定

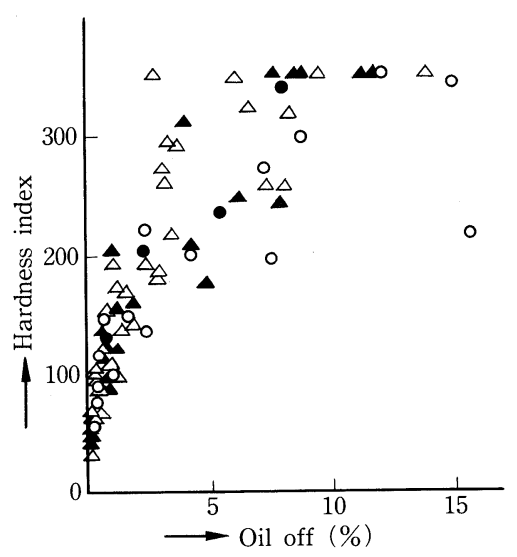

For marks, see Fig.- 1

Fig. -7 Plot of hardness index $v$ s oil-off value for bakery fat spread.

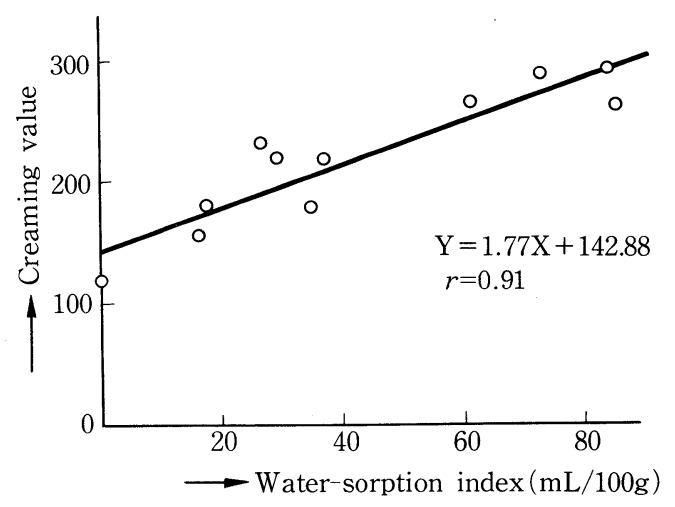

Fig.-8 Plot of creaming value (max.) vs watersorption index for bakery fat spread sweetened. 
が事実上不可能に近い場合でも oil-off 値の低いも の, 特に $10 \%$ 以下之水分が多いにもかかわらず保型性 の良い製品があった。

なお,物理的特数と化学的組成との関連では, その 1 例 として家庭用マーガリン類 ${ }^{6)}$ で高い相関があった SFC $\left(10^{\circ} \mathrm{C}\right)$ と多価不飽和脂肪酸 $(18: 2+18: 3) \%$ との関係 を，業務用ということから $20^{\circ} \mathrm{C}$ での $\mathrm{SFC}$ で検討する と,この両者間にほとんど相関 $(r=0.55)$ がみられな かった。これは業務用マーガリン類の場合 ${ }^{1)}$ 上同様で,

Table-3 に示したように業務用ファットスプレッドの 原料油脂にはもともとリノール酸が少ないこと，また硬 化魚油配合の有無による影響もあるためであろう。いず れにしても業務用ファットスプレッドの物理的性状は原 料油脂の組成だけでなく, 糖や乳化剂, 乳化安定剂, 糊 料のような多くの要因の影響を加味して考える必要があ るようである。

放糖製品のクリーミング性と吸水性の関連について は, Fig.-8に示すようにクリーミング時間中の最高ク リーミング価が吸水量指数之高い相関があり $(r=0.91)$, クリーミング性の良いものほよ゙吸水性も良いことを示し た。
終わりに, 分析にご協力を頂いた木下葉子検查部長, 牛草寿昭技術部長代理並びに岡本隆久博士, 青山 稔博 士, 村上千秋技術課長及び桜井傑君に深謝します。

〔平成 2 年 $(1990$ 年) 6 月 23 日受理〕

\section{文献}

1) 岡本隆久, 丸山武紀, 兼松 弘, 新谷 勛, 油化学, 38, 177, (1989)

2）農林省告示第 522 号（昭和 29 年 7 月 28 日）: 最終改 正，農林水産省告示第 18 号（平成 2 年 1 月 10 日）

3) $\mathrm{CAC} / \mathrm{RS} 32-1969$, Recommended International Standard for Margarine.

4) 岡本隆久, 丸山武紀, 兼松 弘, 新谷 㖵, 油化学, 39, 271 (1990)

5) 塚本正人, フードケミカル, 1987-8, 59 (1987)

6) 小曰山正剛, 丸山武紀, 兼松 弘, 新谷 勛, 松本 太郎, 油化学, 36, 594 (1987)

7) 小曰山正剛, 丸山 武紀, 兼松 弘, 新谷 勛, 油化学 投稿中, “家庭用調理用マーガリンの品質特性について”

8）村上千秋, 丸山武紀, 新谷 勛, 食衛誌, 29, 235(1988)

9）村上千秋, 丸山武紀, 新谷 勛, 食衛誌, 30, 307(1989)

10）兼松 弘, 丸山武紀, 新谷 勛, 今村正男, 栄養上食 糧, 31, 415 (1978)

11) M.-A. Flyvohlm, G.D. Nielsen, A. Andersen, Z. Lebensm. Unters. Forsch., 179, 427 (1984)

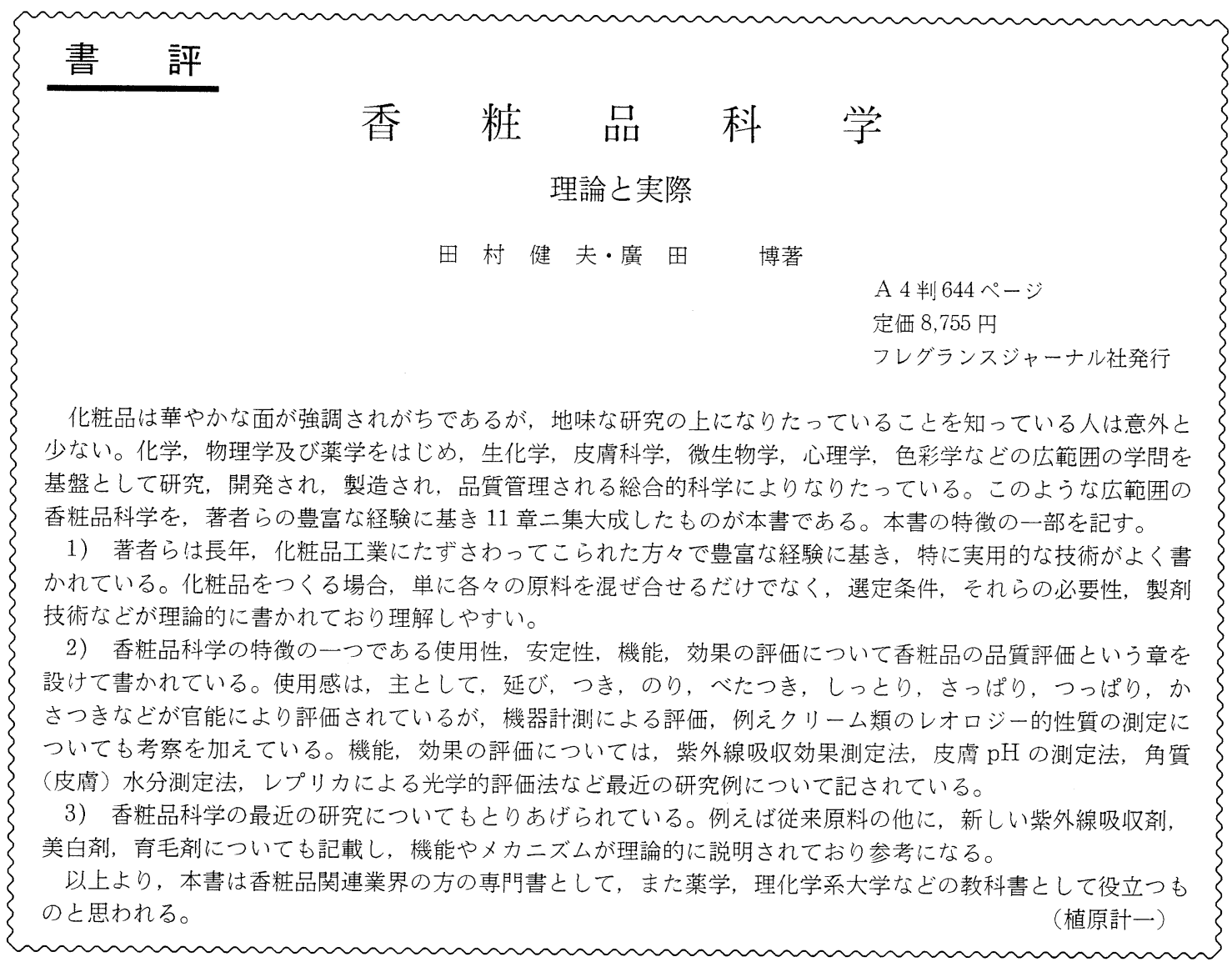

